Article

\title{
In Vivo Assessment of Resistant Starch Degradation by the Caecal Microbiota of Mice Using RNA-Based Stable Isotope Probing-A Proof-of-Principle Study
}

\author{
Elena Herrmann ${ }^{1,2}$, Wayne Young ${ }^{3,4,5}$, Verena Reichert-Grimm ${ }^{2}$, Severin Weis ${ }^{1}$, \\ Christian U. Riedel ${ }^{2}$, Douglas Rosendale ${ }^{6}$, Halina Stoklosinski ${ }^{6}$, Martin Hunt ${ }^{6}$ \\ and Markus Egert 1,* \\ 1 Institute of Precision Medicine, Faculty of Medical \& Life Sciences, Furtwangen University, \\ 78054 Villingen-Schwenningen, Germany; elena.herrmann@hs-furtwangen.de (E.H.); \\ severin.weis@hs-furtwangen.de (S.W.) \\ 2 Institute of Microbiology and Biotechnology, University of Ulm, 89069 Ulm, Germany; \\ verena.grimm@gmx.de (V.R.-G.); christian.riedel@uni-ulm.de (C.U.R.) \\ 3 AgResearch Limited, Food Nutrition and Health Team, Grasslands Research Centre, \\ Palmerston North 4474, New Zealand; wayne.young@agresearch.co.nz \\ 4 Riddet Institute, Massey University, Palmerston North 4474, New Zealand \\ 5 High-Value Nutrition, National Science Challenge, University of Auckland, Auckland 1142, New Zealand \\ 6 The New Zealand Institute for Plant \& Food Research Limited, Palmerston North 4474, New Zealand; \\ douglas.rosendale@plantandfood.co.nz (D.R.); halina.stoklosinski@plantandfood.co.nz (H.S.); \\ martin.hunt@plantandfood.co.nz (M.H.) \\ * Correspondence: markus.egert@hs-furtwangen.de; Tel.: +49-7720-307-4554
}

Received: 22 November 2017; Accepted: 30 January 2018; Published: 6 February 2018

\begin{abstract}
Resistant starch (RS) is the digestion resistant fraction of complex polysaccharide starch. By reaching the large bowel, RS can function as a prebiotic carbohydrate, i.e., it can shape the structure and activity of bowel bacterial communities towards a profile that confers health benefits. However, knowledge about the fate of RS in complex intestinal communities and the microbial members involved in its degradation is limited. In this study, 16S ribosomal RNA (rRNA)-based stable isotope probing (RNA-SIP) was used to identify mouse bowel bacteria involved in the assimilation of $\mathrm{RS}$ or its derivatives directly in their natural gut habitat. Stable-isotope $\left[\mathrm{U}^{13} \mathrm{C}\right]$-labeled native potato starch was administrated to mice, and caecal contents were collected before $0 \mathrm{~h}$ and $2 \mathrm{~h}$ and $4 \mathrm{~h}$ after administration. 'Heavy', isotope-labeled $\left[{ }^{13} \mathrm{C}\right] \mathrm{RNA}$ species, presumably derived from bacteria that have metabolized the labeled starch, were separated from 'light', unlabeled $\left[{ }^{12} \mathrm{C}\right] \mathrm{RNA}$ species by fractionation of isolated total RNA in isopycnic-density gradients. Inspection of different density gradients showed a continuous increase in 'heavy' 16S rRNA in caecal samples over the course of the experiment. Sequencing analyses of unlabeled and labeled $16 \mathrm{~S}$ amplicons particularly suggested a group of unclassified Clostridiales, Dorea, and a few other taxa (Bacteroides, Turicibacter) to be most actively involved in starch assimilation in vivo. In addition, metabolic product analyses revealed that the predominant ${ }^{13} \mathrm{C}$-labeled short chain fatty acid (SCFA) in caecal contents produced from the $\left[\mathrm{U}^{13} \mathrm{C}\right]$ starch was butyrate. For the first time, this study provides insights into the metabolic transformation of RS by intestinal bacterial communities directly within a gut ecosystem, which will finally help to better understand its prebiotic potential and possible applications in human health.
\end{abstract}

Keywords: resistant starch; gut microbiota; RNA-SIP; Clostridiales; Dorea 


\section{Introduction}

The large bowel of humans and other mammals harbors a complex and highly diverse microbiota [1]. Although a unique community structure is observed in each individual [2], the functional capacities encoded by this microbiota are largely shared between individuals [3]. Because of the mutual metabolic activities of host and microbiota, the gut microbiota can be regarded as a separate 'organ' [4] that enables the host to gain energy from substrates that are otherwise inaccessible [5,6]. Resistant starch (RS), as found in raw potatoes, is 'resistant' to digestion by pancreatic enzymes in the small bowel of the host and, hence, able to reach the large bowel, where it is utilized by distinct members of the colonic microbiota [7,8]. While starch from raw potatoes is considered resistant to digestion due to a high amylose content (Type 2 RS), other types of starch are resistant due to physical inaccessibility (Type 1, e.g., in seeds and grains), retrogradation caused by cooking (Type 3) or deliberate chemical modification (Type 4) $[9,10]$. Consumption of such non-digestible carbohydrates may selectively stimulate and enrich for bacteria that transform the fermentable substrates into diverse short chain fatty acids (SCFA) which in turn are known to positively influence host metabolism, physiology, nutrition and immune function [11,12]. As compositional changes in the large bowel community are linked to several gastrointestinal disorders, such as inflammatory bowel disease, but also to obesity, allergies and diabetes [13], stimulation of beneficial members of the colonic community to boost health-promoting intestinal fermentation might be of considerable importance for human health.

A large number of studies have shown a selective modulation of the large bowel microbiota structure by diet-based interventions [14]. However, detailed investigations of which bacterial groups are directly using RS fractions and tracking the fate of RS carbon atoms in complex intestinal ecosystems are still scarce, even though there is increasing evidence for the health benefits conferred by RS [9,15], including its potential clinical application in the therapy and maintenance of gastrointestinal health [16]. It is therefore important to define which kind of bacteria are actually responsible for starch degradation under in situ conditions, as this may lead to better predictions of community structures when being altered by dietary modifications. Previous in vivo studies have reported increases in bacterial taxa such as Bifidobacterium, Ruminococcus, Lactobacillus and Roseburia due to ingestion of RS [17-20]. However, approaches to characterize intestinal community profiles upon dietary modifications are usually biased by enrichments and are often solely based on 16S ribosomal RNA (rRNA) gene sequencing techniques that do not provide a direct link between specific bacterial groups and their ecological function in situ. Knowledge that sheds light on the dynamics of prebiotic carbohydrate utilization and its fate directly within intestinal environments is essential in order to better understand the role of the involved microorganisms and the effects on human physiology. Therefore, the use of molecular techniques that couple the phylogenetic identity of microorganisms to their ecological function are fundamental for in-depth analyses of the bowel microbiota.

The introduction of stable isotope probing (SIP) in microbial ecology represents a significant advantage in the identification of bacteria with specific metabolic capacities under in situ conditions [21,22]. This approach depends on the substrate-dependent incorporation of a stable isotope, predominantly ${ }^{13} \mathrm{C}$, into biomarkers (e.g., nucleic acids) of microorganisms that are involved in the assimilation process of interest [23-25]. In particular RNA-based SIP experiments [26] have gained attention. RNA shows a greater sensitivity in response to metabolic conditions compared to DNA, due to a faster synthesis rate, which is independent of cellular replication processes. This leads to a quicker labeling of RNA within shorter incubation times compared to DNA [23,27]. Initially applied to study phenol degradation processes in an industrial bioreactor [27], RNA-SIP has recently been shown to be suited to link structure and function in intestinal habitats as well and was, therefore, used for the analysis of assimilating processes of simple and more complex sugars, including prebiotics such as RS and inulin [28-33].

The aim of this study was to identify bacteria that assimilate $\left[\mathrm{U}^{13} \mathrm{C}\right]$-labeled potato starch, a source of RS, in vivo in a complex caecal community resident in mice. We observed incorporation of the 
${ }^{13} \mathrm{C}$-label into bacterial $16 \mathrm{~S}$ rRNA only $2 \mathrm{~h}$ after oral administration of $\left[\mathrm{U}^{13} \mathrm{C}\right]$ starch to the mice. Phylogenetic analysis of unlabeled and labeled $16 \mathrm{~S}$ rRNA pools revealed slight differences in the caecal microbiota structure, indicating microbial taxa involved in starch degradation. In addition, metabolite screening by gas chromatography-mass spectrometry (GC-MS) analysis showed label incorporation mainly into butyrate. To the best of our knowledge, our results represent the second report worldwide using RNA-SIP under the in vivo conditions of a vertebrate intestinal system [30], and the first one using RS.

\section{Materials and Methods}

\subsection{Animal Information}

Animal experiments were approved by the ethical committee for animal experimentation of the University of Ulm and the responsible legal authority (Regierungspräsidium Tübingen, Tübingen, Baden-Württemberg, Germany, animal license TVA1238). In total, nine 8-week-old C57BL/6J mice of both sexes were used. The animals were raised at the animal facility of Ulm University in a specific pathogen-free (SPF) environment at $21{ }^{\circ} \mathrm{C}$ and $50-55 \%$ humidity on a $14 \mathrm{~h} / 10 \mathrm{~h}$ light/dark cycle, and provided a standard laboratory diet (61\% carbohydrates, $27 \%$ protein, $12 \%$ fat; Mouse-Breeding fortified, ssniff, Soest, Germany) and water ad libitum.

\subsection{Feeding Experiment with Isotope-Labeled Raw Potato Starch}

Mice were randomly assigned into three groups of three animals each. At the start, animals of two groups received $0.5 \mathrm{~mL}$ of a phosphate-buffered saline solution ( $\mathrm{pH}$ 7.0; PBS; Thermo Fisher Scientific, Waltham, MA, USA) suspended with $\sim 0.4 \mathrm{~g}$ of uniformly $(98 \%)$ isotope-labeled $\left[{ }^{13} \mathrm{C}\right]$ starch extracted from raw potatoes (IsoLife, Wageningen, The Netherlands) via oral gavage into the stomach. The placebo control group received $0.5 \mathrm{~mL}$ of a PBS solution $(\mathrm{pH} \mathrm{7.0)}$ without starch. Animals were sacrificed at $0 \mathrm{~h}$ (placebo control group) or $2 \mathrm{~h}$ and $4 \mathrm{~h}$ after starch administration by cervical dislocation and the entire gastrointestinal tract (GIT) was immediately dissected post mortem using sterile surgical instruments. The caecum section was opened individually, and contents were collected from each animal. Samples were resuspended in $1 \mathrm{~mL}$ of sterile RNAlater (Qiagen, Hilden, Germany) and stored at $-80^{\circ} \mathrm{C}$ until further analyses.

\subsection{RNA Extraction, Isopycnic Ultracentrifugation, Gradient Fractionation, Reverse Transcription}

Bacterial cells from all samples were pelleted for RNA extraction by centrifugation for $20 \mathrm{~min}$ at $4{ }^{\circ} \mathrm{C}$ and $3220 \times g$. To remove residual RNAlater, pellets were washed with PBS and centrifuged again. Total RNA from $\sim 0.1 \mathrm{~g}$ of caecal material was extracted and purified from co-extracted genomic DNA as previously described [32]. RNA integrity was checked with an RNA 6000 NanoLabChip using an Agilent 2100 Bioanalyzer (Agilent Technologies, Inc., Santa Clara, CA, USA) and quantified with a Nanodrop ND-1000 spectrophotometer (Thermo Fisher Scientific, Waltham, MA, USA). Absence of DNA was verified by PCR (Mastercycler Pro S, Eppendorf, Hamburg, Germany) targeting 16S rRNA genes using the universal bacterial primer pair F_Bact 1369 and R_Prok 1492 [34].

To determine the general caecal microbiota structure in each individual mouse prior to the density dependent separation via isopycnic density gradient ultracentrifugation, total caecal RNA from each mouse was converted to complementary DNA (cDNA) in technical duplicates by using the SuperScript VILO cDNA Synthesis Kit (Life Technologies, Camarillo, CA, USA) according to the manufacturer's instructions.

In order to identify bacteria distinctly involved in starch degradation, RNA from individual mice was pooled according to experimental group (control, $2 \mathrm{~h}$, and $4 \mathrm{~h}$ of incubation with starch) in equal ratios to yield $\sim 600 \mathrm{ng}$ per pool, respectively. Subsequently, each RNA pool was separated by isopycnic density gradient ultracentrifugation according to their buoyant density as described elsewhere [31] with minor modifications. In brief, RNA was added to a cesium trifluoroacetate 
(CsTFA) centrifugation solution [31] and adjusted to an average starting density of $\sim 1.789 \mathrm{~g} \mathrm{~mL}^{-1}$ that corresponded to a refractive index of $1.3724 \pm 0.0001$, which was determined using an AR200 refractometer (Reichert, Buffalo, NY, USA). The RNA-loaded centrifugation solution was filled into $6 \mathrm{~mL}$ crimp top ultracentrifugation tubes (Sorvall, Waltham, MA, USA) and centrifuged at $\sim 130,000 \times \mathrm{g}$ and $20^{\circ} \mathrm{C}$ for $65 \mathrm{~h}$ using a $65 \mathrm{~V} 13$ vertical rotor (Sorvall, Waltham, MA, USA) [35]. After centrifugation, density gradients were fractionated into 15 fractions (each $\sim 400 \mu \mathrm{L}$ ) as described previously [31]. For each fraction, the density was determined by measuring the refraction of the solution, which was correlated against a previously established calibration curve. The last two fractions, usually containing water, were excluded from the analysis. RNA from each fraction was recovered as described previously [31] and stored at $-80{ }^{\circ} \mathrm{C}$ until further analysis. This density-dependent RNA fractionation was repeated three times independently for each RNA pool, i.e., in three technical replicates.

Total RNA obtained from each fraction was finally converted to cDNA as described above.

\subsection{Quantification of $16 S$ rRNA in Gradient Fractions}

Quantity of bacterial 16S rRNA in each density fraction was measured by quantitative polymerase chain reaction (RT-qPCR) [36] in a two-step assay using reverse transcribed RNA (cDNA) as template. Amplification reactions were performed in qPCR triplicates according to a previously published method [31]. Afterwards, RNA concentrations were calculated by means of correlation to an internal standard curve generated from serial dilutions of a calibrator pool consisting of equal amounts of genomic DNA isolated from Faecalibacterium prausnitzii A2-165, Escherichia coli DH5- $\alpha$, Lactobacillus plantarum WCSF1 and Clostridium perfringens $\mathrm{CH} 05$ using the Rotor-Gene Software (version 1.6; Qiagen, Valencia, CA, USA). RNA concentrations in each gradient fraction were averaged across the qPCR triplicates and expressed as percentage RNA concentration relative to the maximum quantity detected among all fractions within the gradient [32].

\section{5. $16 S$ rRNA Amplicon Library Construction and Sequencing}

To assess the general caecal microbiota structure in each individual mouse prior to density-dependent separation, $16 \mathrm{~S}$ rRNA gene amplicon libraries were constructed from the respective reverse transcribed caecal RNA samples.

For the identification of distinct bacterial taxa involved in $\left[\mathrm{U}^{13} \mathrm{C}\right]$ starch assimilation, $16 \mathrm{~S}$ rRNA gene amplicon libraries were constructed from density-separated and reverse-transcribed RNA obtained from selected SIP fractions. SIP fractions 8-10 contained the bulk of $16 \mathrm{~S}$ rRNA present in samples from control mice that did not receive any $\left[\mathrm{U}^{13} \mathrm{C}\right]$ starch $(0 \mathrm{~h})$. These fractions were considered to represent unlabeled bacterial populations and were thus defined 'light' fractions. In caecal samples of mice fed with $\left[\mathrm{U}^{13} \mathrm{C}\right]$ starch, gradient fractions 5-7 contained the bulk of RNA, which was consequently considered to be 'heavy', i.e., ${ }^{13} \mathrm{C}$-labeled, representing bacteria that particularly assimilated the $\left[\mathrm{U}^{13} \mathrm{C}\right]$ starch and sequestered the isotope label in their RNA.

All amplicon libraries were prepared by NZGL Genomics Limited (Palmerston North, New Zealand) and comprised a segment of the V3 and V4 regions of the bacterial 16S rRNA gene, which was amplified in a dual-indexed single step PCR reaction and resulted in amplicons of $\sim 459$ bp. Unique indexed libraries were quality checked with a Bioanalyzer DNA 1000 LabChip (Agilent Technologies, Inc., Santa Clara, CA, USA), quantified by fluorometric measurements using a Qubit dsDNA HS assay kit (Life Technologies, Camarillo, CA, USA) and finally pooled in equimolar amounts for sequencing on a Illumina MiSeq platform using Illumina MiSeq 500 cycle Kit_V2 chemistry $(2 \times 250$ base PE; Illumina, San Diego, CA, USA).

\section{6. $16 S$ Ribosomal RNA Phylogenetic Analysis and Statistics}

Amplicon sequence reads were processed using QIIME 1.8 (available on: http://qiime. sourceforge.net/) [37] as previously described [32]. 16S rRNA obtained from the individual mouse caecal contents were sequenced in duplicate technical replicates, while 16S rRNA obtained from 
each of the three 'light' (5-7) and three 'heavy' (8-10) gradient fractions were sequenced in triplicate, respectively. However, variation between technical replicates were minimal, so sequence reads from technical replicates were analyzed together in order to maximize the sequencing depth.

Alpha diversity in gradient fractions was calculated using Faith's phylogenetic diversity estimate across 10 iterations based on the minimum number of reads (5646) implemented through the core_diversity_analyses.py script.

Statistical tests of the sequencing data were conducted in R 3.3.2 [38]. A taxon was considered to be ${ }^{13} \mathrm{C}$-labeled when its proportion in 'heavy' gradient fractions was significantly higher than in the 'light' counterpart fractions at each time point. Therefore, differences in the taxon abundance between 'heavy' and 'light' were analysed by non-parametric permutation ANOVA using density as factor. The tests were implemented using the perm.anova function in the RVAideMemoire package for $R$ [39] with 2000 permutations. Differences in alpha diversity were analysed using two-factor ANOVA with time and density as factors. All detected differences with a $p$-value $\leq 0.05$ were considered significant, while trends with limited significance were defined as $p>0.05$ but $\leq 0.10$. Hierarchical cluster analysis of bacterial profiles retrieved from 'heavy' and 'light' fractions was performed using distances calculated from centered Pearson's correlation and average linkage clustering.

In addition to the classification results obtained by QIIME, the three most abundant OTUs of bacterial taxa that differed significantly $(p \leq 0.05)$ between 'light' and 'heavy' RNA fraction, were classified using BLAST [40]. The relatedness of the respective OTUs to the next cultured bacterial species suggested by BLAST was visualized in a dendrogram created with the CLC Genomic Workbench (version 8.5.2; Qiagen, Hilden, Germany) using the neighbor joining algorithm, Kimura80 as nucleotide distance measure and 10.000 replications for the bootstrap analysis.

All sequencing data obtained in this study were submitted to GenBank and are publicly available under the accession number PRJNA412932.

\subsection{Organic Acid Analysis and Isotope Labeling Detection}

Organic acid concentrations were analysed by gas chromatography (GC). Caecal RNAlater supernatants were diluted five-fold with $0.01 \mathrm{M}$ PBS containing 2-ethylbutyric acid $(6.25 \mathrm{mM})$ as an internal standard. A $500 \mu \mathrm{L}$ aliquot of the diluted supernatant was acidified with $250 \mu \mathrm{L}$ concentrated hydrochloric acid and $1000 \mu \mathrm{L}$ diethyl ether were added. After thorough mixing to allow acids to solubilise in the diethyl ether, the sample was centrifuged at $10,000 \times \mathrm{g}$ for $5 \mathrm{~min}$ at $4{ }^{\circ} \mathrm{C}$ to complete phase separation. The diethyl ether phase was stored at $-80^{\circ} \mathrm{C}$ until derivatisation for GC-analysis with flame ionization detection (FID) (for organic acids concentrations) and GC-mass spectrometry (MS) (for isotope analysis).

Organic acid concentrations were quantified by GC-FID based on a previously published method [41]. In a capped GC vial, $100 \mu \mathrm{L}$ of the diethyl ether phase was derivatised with $20 \mu \mathrm{L} \mathrm{N}$-tert-butyldimethylsilyl- $N$-methyltrifluoroacetamide (MSTFA) with $1 \%$ tert-butyldimethylchlorosilane (Sigma-Aldrich, Auckland, New Zealand) by heating to $80^{\circ} \mathrm{C}$ in a water bath for $20 \mathrm{~min}$. To allow complete derivatisation, the samples were left for $48 \mathrm{~h}$ at room temperature before analysis. Standards containing 2-ethylbutyric acid ( $5 \mathrm{mM})$ as an internal standard were prepared for derivatisation alongside the samples. Analysis was performed on a capillary GC system (GC-2010 Plus; Shimadzu, Kyoto, Japan) equipped with a FID and fitted with a Restek column (Rtx-1, $30 \mathrm{~m} \times 0.25 \mathrm{~mm} \times 0.25 \mu \mathrm{m}$ ) (Bellefonte, PA, USA). The carrier gas was helium with a total flow rate of $21.2 \mathrm{~mL} / \mathrm{min}$ and pressure of $131.2 \mathrm{kPa}$. Make-up gas was nitrogen. The temperature program began at $70^{\circ} \mathrm{C}$ increasing to $115^{\circ} \mathrm{C}$ at $6{ }^{\circ} \mathrm{C} / \mathrm{min}$, with a final increase to $300{ }^{\circ} \mathrm{C}$ at $60^{\circ} \mathrm{C} / \mathrm{min}$, holding for $3 \mathrm{~min}$. Flow control mode was set to linear velocity of $37.5 \mathrm{~cm} / \mathrm{s}$. The injector temperature was $260^{\circ} \mathrm{C}$ and detector temperature was $310^{\circ} \mathrm{C}$. Samples were injected $(1 \mu \mathrm{L})$ with a split injection (split ratio: 10:1). The GC instrument was controlled and data processed using Shimadzu GC Work Station LabSolutions Version 5.3 software. Organic acids were quantified by comparison with standard curves generated from authentic standards run in the same batch. 
Isotope analysis was performed using diethyl ether extracts as described above, evaporated to dryness, derivatised with $50 \mu \mathrm{L}$ of methoxyamine, $20 \mathrm{mg} / \mathrm{mL}$ ) at $40{ }^{\circ} \mathrm{C}$ for $90 \mathrm{~min}$, then with MSTFA $(80 \mu \mathrm{L})$ at $40{ }^{\circ} \mathrm{C}$ for $30 \mathrm{~min}$ and analysed on an Agilent 7890B GC system coupled to an Agilent 5977A MSD mass spectrometer (Agilent Technologies, Inc., Santa Clara, CA, USA) fitted with a Restek column (Rxi-5ms, $30 \mathrm{~m} \times 0.25 \mathrm{~mm} \times 0.25 \mu \mathrm{m}$ ) (Bellefonte, PA, USA). The carrier gas was helium at $8.8 \mathrm{psi}$ with an average linear velocity of $39.6 \mathrm{~cm} / \mathrm{s}$. Samples were injected $(1 \mu \mathrm{L})$ with a split injection (split ratio: 10:1). The injection temperature was $250{ }^{\circ} \mathrm{C}$, with oven temperature of $35^{\circ} \mathrm{C}$ for $2 \mathrm{~min}$, then increasing to $90^{\circ} \mathrm{C}$ at $5{ }^{\circ} \mathrm{C} / \mathrm{min}$, and to $300^{\circ} \mathrm{C}$ at $15^{\circ} \mathrm{C} / \mathrm{min}$. Electron ionisation energy was $70 \mathrm{eV}$. Authentic standards were run alongside, as described for GC-FID above. Compounds were identified using the retention times of authentic standards run in the same batch, and masses by comparison with the NIST11 mass spectral database. Mass spectra were used, in the absence of established Vienna Pee Dee Belemnite ${ }^{13} \mathrm{C}$ mass standard, to calculate atom percent excess (APE) according to Equation (1) [42] where (atom \%) E $_{\mathrm{E}}$ is the ${ }^{13} \mathrm{C}$ abundance of the RS-fed samples at times $2 \mathrm{~h}$ and $4 \mathrm{~h}$, and (atom \%) ${ }_{\mathrm{B}}$ is the ${ }^{13} \mathrm{C}$ abundance of the baseline (time $0 \mathrm{~h}$ ) samples. The (atom \%) values were calculated according to Equation (2) [42], from the following $t$-butyl-dimethyl-silyl organic acid derivative $m / z$ ratios: acetate, M-119/117; butyrate, M-147/145; and lactate, M-119/117. We were unable to resolve propionate from a contaminating peak with this method.

$$
\begin{gathered}
\mathrm{APE}=(\text { atom \% })_{\mathrm{E}}-(\text { atom } \%)_{\mathrm{B}} \\
\text { Atom } \%{ }^{13} \mathrm{C}=\left(\left[{ }^{13} \mathrm{C}\right] /\left(\left[{ }^{12} \mathrm{C}\right]+\left[{ }^{13} \mathrm{C}\right]\right)\right) \times 100
\end{gathered}
$$

\section{Results}

\subsection{General Microbiota Structure in the Used Animals Prior to Gradient Separation}

To determine the general bacterial microbiota composition prior to the density-dependent separation of extracted RNA, 16S rRNA sequences of individual caecal contents of all mice used in the experiment were analyzed.

Sequencing analysis of these samples yielded a total of 75,549 paired-end sequences. The average number of reads per sample were $8394 \pm 2148$ (range 5646-12,512 reads). Collectively, these sequences were assigned to 69 bacterial genera affiliated with 33 families, 19 orders, 14 classes and 7 phyla, representing the entire caecal community across all samples.

Firmicutes and Bacteroidetes were the most prevalent phyla within the caecal communities, whereas Proteobacteria as well as unclassified Bacteria represented minor taxa (Supplementary Table S1). Although a slight variation between individual mice was observed at lower taxonomic levels, Lachnospiraceae and Ruminococcaceae were the most prevalent families (Supplementary Table S1). The most dominant taxa classified to the most detailed taxonomic level available were unclassified Lachnospiraceae, followed by unclassified Clostridiales, unclassified Ruminococcaceae and Prevotella spp. (Supplementary Figure S1).

\subsection{Density Gradient Formation and Recovery of Stable Isotope-Labeled Bacterial $16 S$ rRNA}

To identify intestinal bacteria involved in the assimilation of $\left[\mathrm{U}^{13} \mathrm{C}\right]$ starch directly in their natural habitat, RNA isolated from caecal contents and pooled for groups of three mice, each, after $0 \mathrm{~h}, 2 \mathrm{~h}$ and $4 \mathrm{~h}$ of feeding with $\left[\mathrm{U}^{13} \mathrm{C}\right]$ starch, were density-separated in order to detect ${ }^{13} \mathrm{C}$-labeled bacterial RNA.

The fractionated gradients showed a linearly decreasing density between $1.757 \mathrm{~g} \mathrm{~mL}^{-1}$ (fraction 13) and $1.854 \mathrm{~g} \mathrm{~mL}^{-1}$ (fraction 1; Figure 1a). Distribution patterns of caecal 16S rRNA sequences within the fractionated density gradients showed that the bulk of RNA isolated from mice that had not received $\left[\mathrm{U}^{13} \mathrm{C}\right]$ starch $(0 \mathrm{~h}$, control RNA) accumulated in the low density fractions 8-10 ( 1.794-1.779 $\mathrm{g} \mathrm{mL}^{-1}$ ), with peak amounts being present in fractions 8 and 9 (Figure 1b). In contrast, caecal RNA isolated from mice fed with $\left[\mathrm{U}^{13} \mathrm{C}\right]$ starch shifted towards the higher density fractions $5-7$ $\left(\sim 1.817-1.802 \mathrm{~g} \mathrm{~mL}^{-1}\right)$ with the maximum amount of RNA detected in fraction 7 after $4 \mathrm{~h}$. Furthermore, 
although after $2 \mathrm{~h}$ the majority of RNA still accumulated in fraction 8 and $9\left(\sim 1.794\right.$ and $\left.\sim 1.786 \mathrm{~g} \mathrm{~mL}^{-1}\right)$, fraction $7\left(\sim 1.802 \mathrm{~g} \mathrm{~mL}^{-1}\right)$ contained more RNA than control fraction 7 (Figure 1b).

(a)

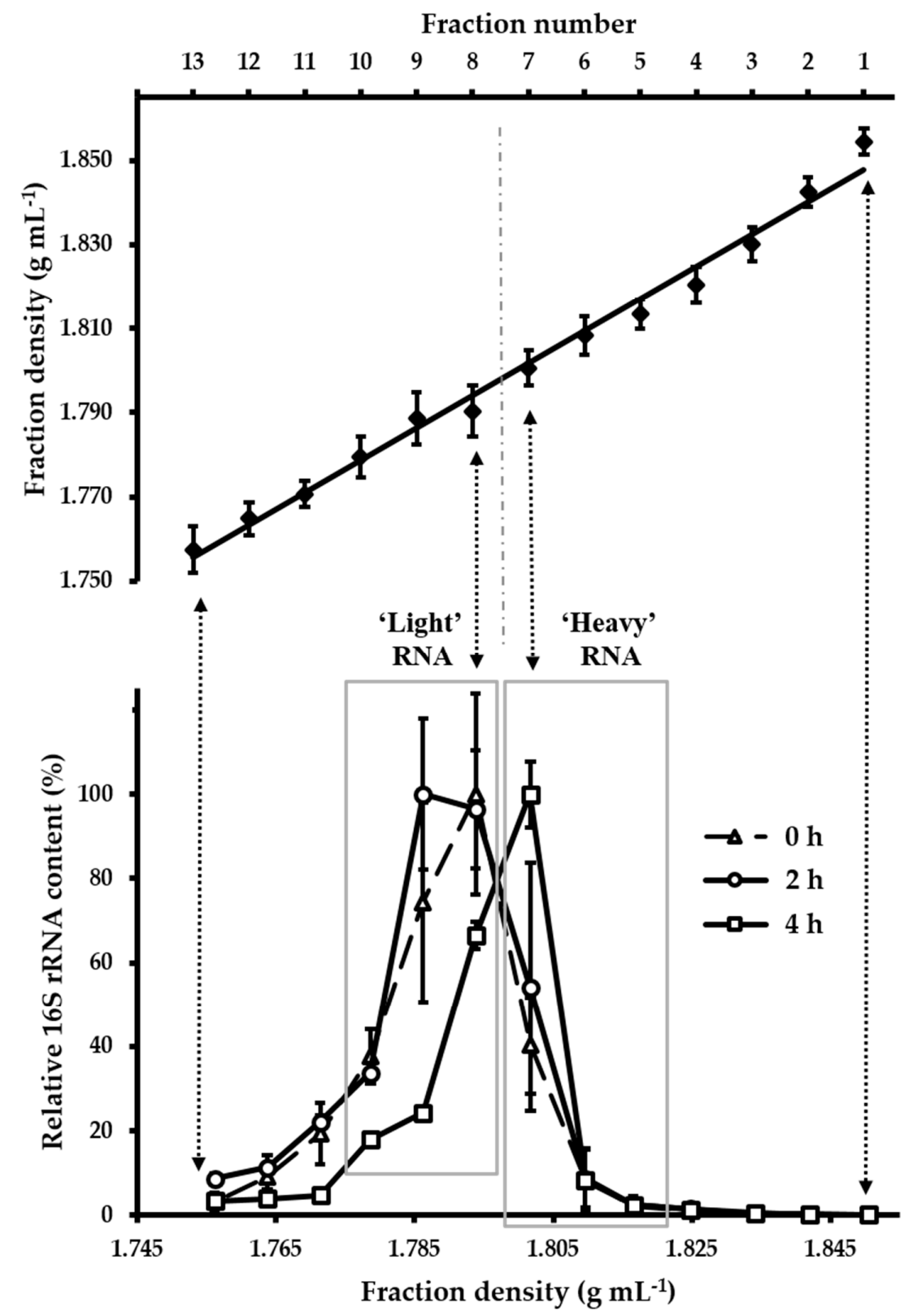

(b)

Figure 1. (a) Density of isopycnic density gradient fractions. Means and standard errors (SEM) of nine gradients are shown. For each fraction, the SEM was $\leq 0.006 \mathrm{~g} \mathrm{~mL}^{-1}$. The vertical dash dot line divides the density gradient into 'heavy' ( $\leq$ fraction 7 ) and 'light' ( $\geq$ fraction 8 ) fractions; (b) Distribution of relative amounts of $16 \mathrm{~S}$ rRNA. RNA from the isopycnic density gradients was collected before $(0 \mathrm{~h})$ or after administration of $\left[\mathrm{U}^{13} \mathrm{C}\right]$ starch $(2 \mathrm{~h}$ and $4 \mathrm{~h})$. Means and SEMs of three technical replicates for each gradient fraction per sampling time are shown. To facilitate comparison between the different gradients, RNA content is calculated as a proportion (\%) of the fraction containing the highest RNA concentration (100\%) per gradient [32]. Boxes indicate 'heavy' and 'light' density fractions analyzed for microbiota composition. Vertical arrows indicate corresponding fraction numbers in $(\mathbf{a}, \mathbf{b})$. 
3.3. Characterisation of Metabolically Active Populations and Identification of Potential [U $\left.{ }^{13} \mathrm{C}\right]$ Starch Degraders by Density Gradient Formation and Recovery of Stable Isotope-Labeled Bacterial 16S rRNA

Sequencing analysis of selected 'light' and 'heavy' gradient fractions yielded a total of 944,665 paired-end sequences. The average number of reads for each sample were 52,481 $\pm 12,338$ (range 34,640-75,739 reads).

Phylogenetic analysis of these samples revealed a complex microbiota structure with Lachnospiraceae, unclassified Clostridiales and Ruminococcaceae 16S rRNA gene sequences relatively dominating the 'light' as well as the 'heavy' communities (Supplementary Figure S2).

Hierarchical cluster analysis revealed community structure profiles of mice $2 \mathrm{~h}$ and $4 \mathrm{~h}$ after administration of $\left[\mathrm{U}^{13} \mathrm{C}\right]$ starch being clearly separated from those detected before the administration of RS (0 h) (Figure 2). In addition, significant differences in Faith's phylogenetic diversity estimate between 'heavy' and 'light' fraction samples $(p=0.038)$ as well as between the different sampling times $(p=0.023)$ were detected (Table 1$)$.

To identify bacteria possibly involved in the degradation of the $\left[\mathrm{U}^{13} \mathrm{C}\right]$ starch, sequencing profiles retrieved form 'heavy' and 'light' SIP fractions at each sampling time were screened for relative differences of individual taxa; $2 \mathrm{~h}$ after administration of $\left[\mathrm{U}^{13} \mathrm{C}\right]$ starch, taxa that showed significantly increased proportions in 'heavy' fractions compared to the corresponding 'light' counterparts included unclassified Clostridiales ( $p=0.03)$ and Dorea spp. $(p=0.03)$. Taxa that tended towards significant increases included Bacteroidaceae $(p=0.07)$, Bacteroides spp. $(p=0.06)$ and Turicibacter spp. $(p=0.08)$. All these groups also showed higher abundances in the 'heavy' RNA $4 \mathrm{~h}$ after starch administration, however, not with statistical significance (Figures 2 and 3 and Supplementary Table S2).

At $4 \mathrm{~h}$, the only taxon that was significantly enriched in 'heavy' compared to 'light' fractions upon RS consumption was Papillibacter $(p=0.05)$. However, since this genus also tended to be enriched in heavy RNA before starch, i.e., label addition, we did not consider this genus as a potential starch degrader here (Supplementary Table S2).

A BLAST-based phylogenetic analysis (Figure 4) of the three most abundant OTUs of the bacterial taxa that differed significantly $(p \leq 0.05)$ between 'light' and 'heavy' RNA fractions, indicated affiliations with Clostridium lactatifermentans and the family Lachnospiraceae (in case of OTUs designated as 'unclassified Clostridiales') and with Clostridium fusiformis and Dorea formicigenerans (in case of OTUs designated as Dorea spp.).

Finally, proportions of a diverse array of sequences affiliated with unclassified Porphyromonadaceae, Prevotella, and Lactobacillus (all $p \leq 0.05$ ), as well as unclassified Ruminococcaceae, unclassified Desulfovibrionaceae (all $p \leq 0.1$ ) and other taxa with smaller population size $(\leq 1 \%$ relative abundance) showed reduced relative abundances in the 'heavy' fractions compared to the 'light' fractions at $2 \mathrm{~h}$ and at $4 \mathrm{~h}$ (Figure 2 and Supplementary Table S2).

Table 1. Faith's phylogenetic diversity estimate in 'heavy' and 'light' density gradient fractions before $(0 \mathrm{~h})$ or $2 \mathrm{~h}$ and $4 \mathrm{~h}$ after administration of $\left[\mathrm{U}^{13} \mathrm{C}\right]$ starch.

\begin{tabular}{|c|c|c|c|c|c|c|c|c|c|}
\hline \multicolumn{10}{|c|}{ Faith's Phylogenetic Diversity Estimate } \\
\hline \multicolumn{10}{|c|}{ PD Whole Tree } \\
\hline & \multicolumn{2}{|c|}{$0 \mathrm{~h}$} & \multicolumn{2}{|c|}{$2 \mathrm{~h}$} & \multicolumn{2}{|c|}{$4 \mathrm{~h}$} & \multicolumn{3}{|c|}{$p$-Value } \\
\hline SIP Fractions & Mean & SEM & Mean & SEM & Mean & SEM & Density & Time & Density $\times$ Time \\
\hline Heavy & 43.53 & 0.42 & 45.39 & 1.34 & 46.35 & 2.04 & \multirow{2}{*}{$0.038 *$} & \multirow{2}{*}{$0.023 *$} & \multirow{2}{*}{0.653} \\
\hline Light & 46.86 & 0.38 & 45.02 & 0.47 & 50.92 & 1.01 & & & \\
\hline
\end{tabular}




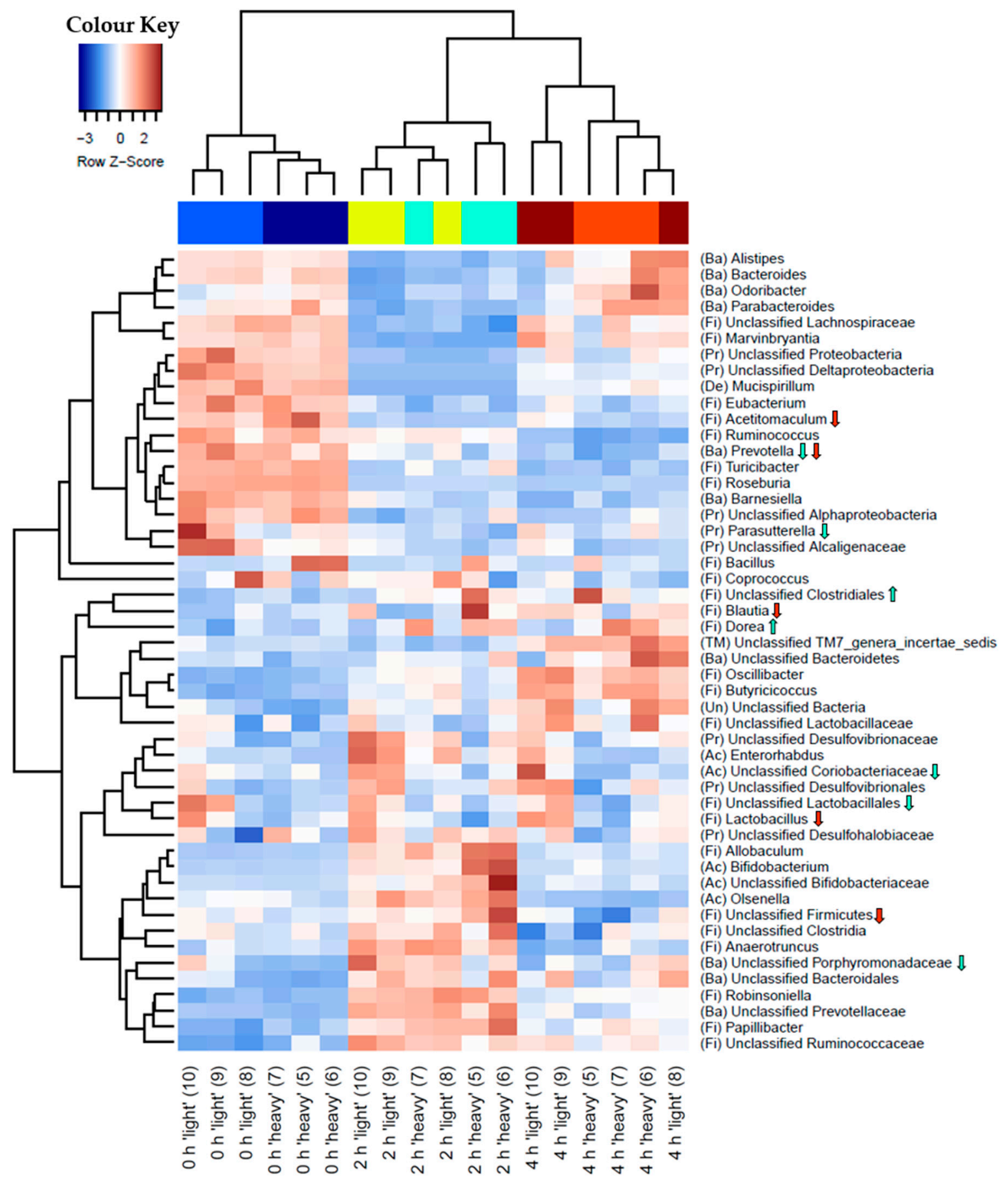

Figure 2. Heatmap of hierarchical clustering of bacterial microbiota composition profiles represented by $16 \mathrm{~S}$ ribosomal RNA (rRNA) amplicons per sample of 'heavy' and 'light' gradient fractions at each sampling time. RNA from caecal contents was isolated before $(0 \mathrm{~h})$ or after provision of $\left[\mathrm{U}^{13} \mathrm{C}\right]$ starch $(2 \mathrm{~h}$ and $4 \mathrm{~h}$ ). The presented community profiles are results of three technical replicates for each fraction per sampling time. Bacteria shown represent the 50 taxa with the highest mean relative abundance across all fraction samples. Heatmap colour (blue to dark red) displays the row scaled relative abundance of each taxon across all samples. The number in parentheses indicates the corresponding fraction number. Letters in parentheses preceding taxonomic labels indicate the phylum $(\mathrm{Ac}=$ Actinobacteria, $\mathrm{Ba}=$ Bacteroidetes, $\mathrm{De}=$ Deferribacteres, $\mathrm{Fi}=$ Firmicutes, $\mathrm{Pr}=$ Proteobacteria, $\mathrm{Ve}=$ Verrucomicrobia, $\mathrm{Un}=$ Unclassified). Arrows indicate either increase or decrease at $p \leq 0.05$ in 'heavy' fractions compared to the corresponding 'light' fractions as calculated by permutation ANOVA with 2000 permutations using density as factor at $2 \mathrm{~h}$ (green arrows) and $4 \mathrm{~h}$ (red arrows). 


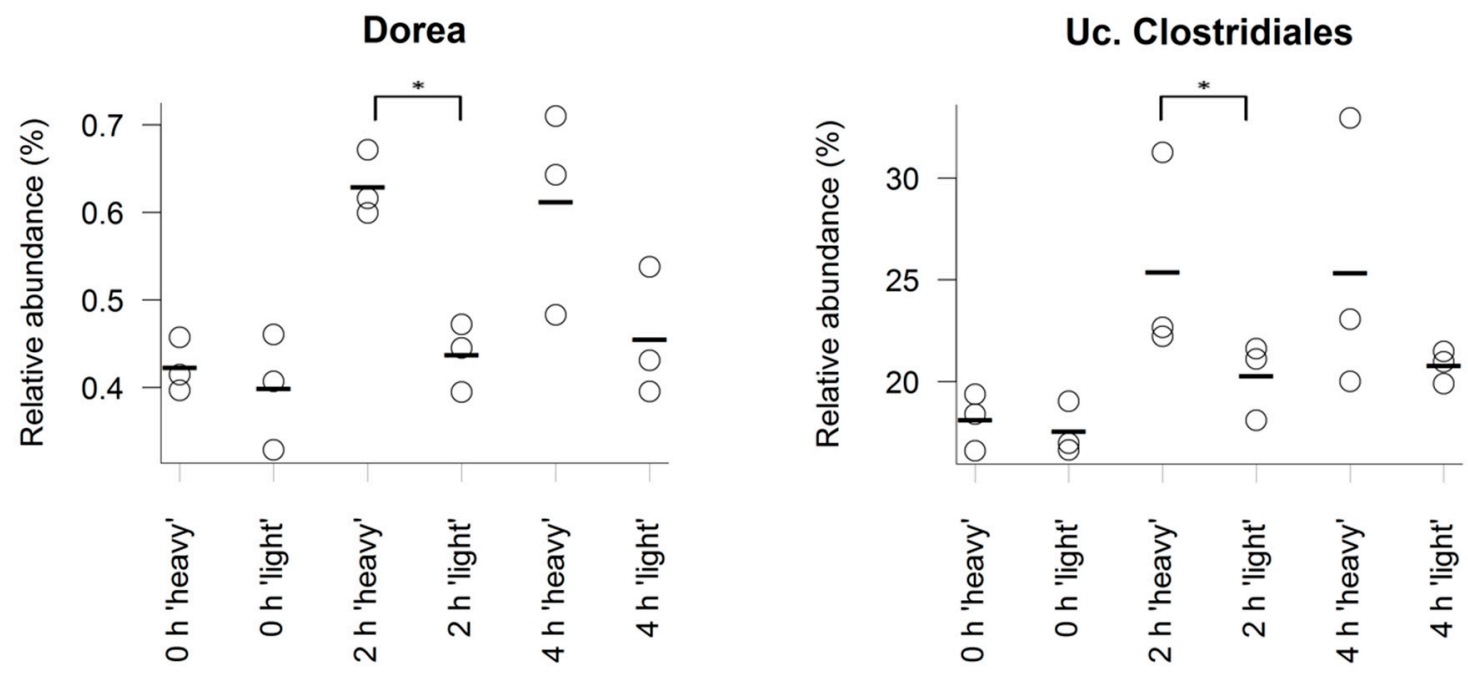

Figure 3. Relative abundance of selected bacterial taxa represented by $16 \mathrm{~S}$ rRNA amplicons in 'heavy' and 'light' SIP fractions. RNA from caecal content was isolated before $(0 \mathrm{~h})$ or after administration $(2 \mathrm{~h})$ of the $\left[\mathrm{U}^{13} \mathrm{C}\right]$ starch. Taxa shown display a significantly $(p \leq 0.05)$ higher mean relative abundance in the 'heavy' gradient fractions compared to the corresponding 'light' fraction samples at $2 \mathrm{~h}$. Points indicate relative abundance in (\%) of the total community ( $n=3$ fractions, each), and lines indicate the mean. * Indicates permutation ANOVA significance with 2000 permutations in relative proportions at $p \leq 0.05$ using density as factor.

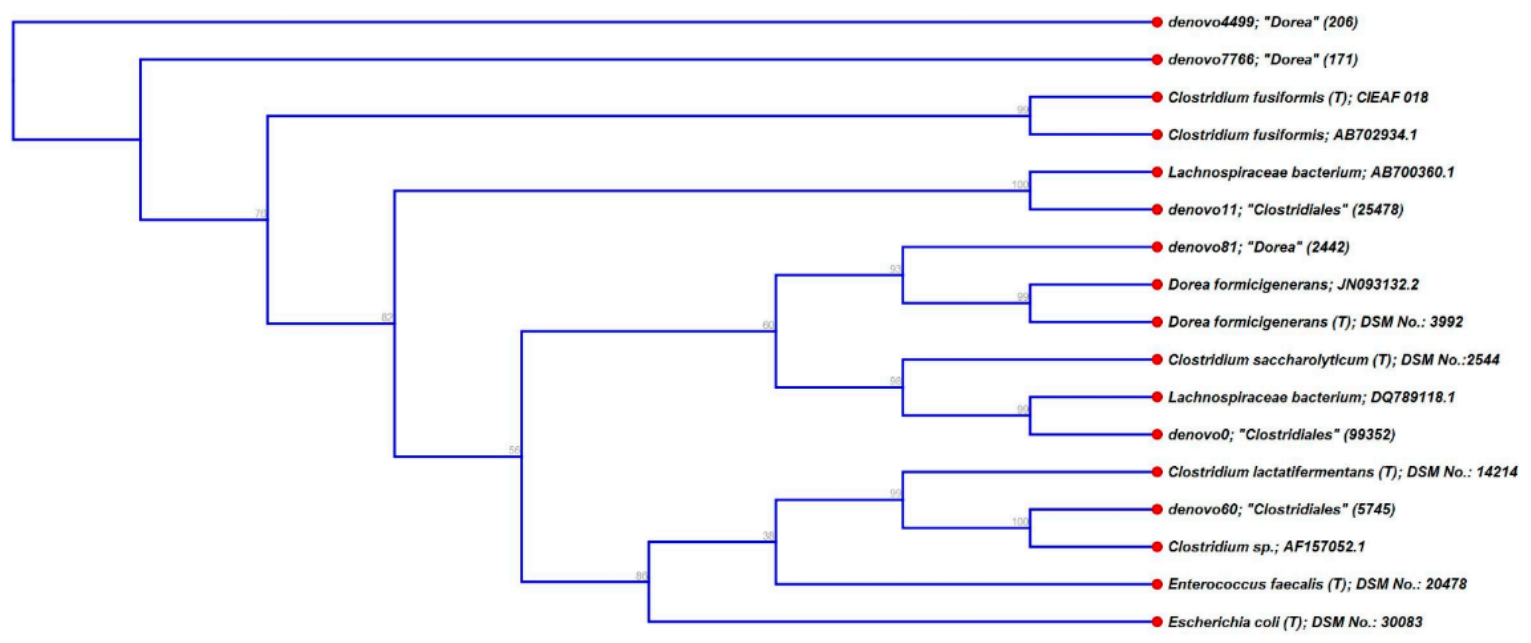

Figure 4. Dendrogram showing the relatedness of the three most abundant OTUs of the bacterial taxa that differed significantly $(p \leq 0.05)$ between 'light' and 'heavy' RNA fractions (i.e., unclassified Clostridiales and Dorea spp.) to their next cultured relatives according to a BLAST search. Escherichia coli and Enterococcus faecalis were used as outgroups.

\subsection{Organic Acid Production and Heavy Isotope Incorporation into Metabolic Products}

To gain further insight into the metabolic activity of the caecal microbiota, GC-FID and GC-MS analysis was performed in supernatants of caecal contents to monitor ${ }^{13} \mathrm{C}$-labeled metabolite formation during the course of $\left[\mathrm{U}^{13} \mathrm{C}\right]$ starch fermentations in each animal. On average, acetate $(\sim 11.8 \mu \mathrm{mol} / \mathrm{mL})$, butyrate $(\sim 3.2 \mu \mathrm{mol} / \mathrm{mL})$, propionate $(1.7 \mu \mathrm{mol} / \mathrm{mL})$, lactate $(0.6 \mu \mathrm{mol} / \mathrm{mL})$, succinate $(0.4 \mu \mathrm{mol} / \mathrm{mL})$ and valerate $(0.2 \mu \mathrm{mol} / \mathrm{mL})$ were the main metabolic end products detected after administration of the $\left[\mathrm{U}^{13} \mathrm{C}\right.$ ] starch dose (average of $2 \mathrm{~h}$ and $4 \mathrm{~h}$; Table 2). However, the metabolite concentrations showed inter-animal differences with on average decreasing amounts of metabolites during the 
course of fermentation (Table 2). Nevertheless, GC-MS analysis revealed label incorporation into acetate, butyrate and lactate (Table 3). Although the amount of ${ }^{13} \mathrm{C}$ in the analyzed metabolites, expressed as atom percent excess (APE), showed inter-animal variations, in each mouse, butyrate was the predominant labeled fermentation product, followed by lactate and acetate $2 \mathrm{~h}$ after the administration of starch. During the course of fermentation, isotope-labeled butyrate as well as acetate were consistently produced from the $\left[\mathrm{U}^{13} \mathrm{C}\right]$ starch, while amounts of ${ }^{13} \mathrm{C}$-labeled lactate concentrations declined after $2 \mathrm{~h}$.

Table 2. Organic acid fermentation products from caecal contents of individual mice before $(0 \mathrm{~h})$ and after administration of resistant starch (RS; $2 \mathrm{~h}$ and $4 \mathrm{~h}$ ). M1 to M9 identify the mouse source for caecal contents at each sampling time.

\begin{tabular}{|c|c|c|c|c|c|c|c|c|c|}
\hline \multicolumn{10}{|c|}{ Fermentation Products } \\
\hline \multicolumn{10}{|c|}{ Concentration ( $\mu \mathrm{mol} / \mathrm{mL}$ Supernatant) } \\
\hline & & $0 \mathrm{~h}$ & & & $2 \mathrm{~h}$ & & & $4 \mathrm{~h}$ & \\
\hline Organic acid (as conjugate base) & M1 & M2 & M3 & M4 & M5 & M6 & M7 & M8 & M9 \\
\hline Formate $(\mathrm{C} 1)$ & $0.3^{\mathrm{a}}$ & $0.3^{\mathrm{a}}$ & $0.3^{\mathrm{a}}$ & $0.3^{\mathrm{a}}$ & $0.3^{\mathrm{a}}$ & $0.3^{\mathrm{a}}$ & $0.3^{\mathrm{a}}$ & $0.3^{\mathrm{a}}$ & $0.3^{\mathrm{a}}$ \\
\hline Acetate (C2) & 17.77 & 16.6 & 18.7 & 18.7 & 13.39 & 6.69 & 10.82 & 7.27 & 14.22 \\
\hline Propionate (C3) & 4.9 & 2.58 & 3.08 & 2.69 & 1.71 & 1.35 & 1.6 & 1.33 & 1.75 \\
\hline Butyrate (C4) & 5.65 & 4.72 & 4.19 & 4.25 & 3.04 & 1.96 & 3.74 & 2.14 & 4.12 \\
\hline Valerate (C5) & 0.23 & 0.17 & 0.17 & 0.26 & 0.22 & 0.13 & 0.16 & 0.12 & 0.18 \\
\hline Caproate (C6) & $0.1^{\mathrm{a}}$ & $0.1^{\mathrm{a}}$ & $0.1^{\mathrm{a}}$ & $0.1^{\mathrm{a}}$ & $0.1^{\mathrm{a}}$ & $0.1^{\mathrm{a}}$ & $0.1^{\mathrm{a}}$ & $0.1^{\mathrm{a}}$ & $0.1^{\mathrm{a}}$ \\
\hline Enanthate (C7) & $0.1^{\mathrm{a}}$ & $0.1^{\mathrm{a}}$ & $0.1^{\mathrm{a}}$ & $0.1^{\mathrm{a}}$ & $0.1^{\mathrm{a}}$ & $0.1^{\mathrm{a}}$ & $0.1^{\mathrm{a}}$ & $0.1^{\mathrm{a}}$ & $0.1^{\mathrm{a}}$ \\
\hline Lactate $(\mathrm{C} 3 ; 2-\mathrm{OH})$ & 0.59 & 0.96 & 3.66 & 0.94 & 0.38 & 0.8 & 0.67 & 0.25 & 0.48 \\
\hline Succinate (C4; 1,4-dicarboxylate) & 0.52 & 0.45 & 0.82 & 0.47 & 0.32 & 0.31 & 0.33 & $0.3^{\mathrm{a}}$ & $0.3^{\mathrm{a}}$ \\
\hline Isobutyrate (C4; 2-methyl-C3) & 0.25 & $0.15^{\mathrm{a}}$ & 0.19 & 0.22 & $0.15^{\mathrm{a}}$ & $0.15^{\mathrm{a}}$ & $0.15^{\mathrm{a}}$ & $0.15^{\mathrm{a}}$ & $0.15^{\mathrm{a}}$ \\
\hline Isovalerate (C5; 3-methyl-C4) & 0.13 & $0.1^{\mathrm{a}}$ & 0.14 & 0.13 & $0.1^{\mathrm{a}}$ & $0.1^{\mathrm{a}}$ & $0.1^{\mathrm{a}}$ & $0.1^{\mathrm{a}}$ & $0.1^{\mathrm{a}}$ \\
\hline
\end{tabular}

${ }^{a}$ At or below detection limit (detection limit for each organic acid shown).

Table 3. Organic acid fermentation product ${ }^{13} \mathrm{C}$ atom percent excess (APE) relative to natural abundance of ${ }^{13} \mathrm{C}$-labeled acid at time $0 \mathrm{~h}$ samples, from caecal contents of individual mice after administration of resistant starch (RS; $2 \mathrm{~h}$ and $4 \mathrm{~h}$ ).

\begin{tabular}{ccccc|ccc}
\hline \multicolumn{1}{c}{${ }^{13}$ C-Labeled Fermentation Products } \\
\hline${ }^{13}$ C Atom Percent Excess (APE) Relative to Natural Abundance of ${ }^{13}$ C-Labeled Acid at Time 0 H Samples \\
\hline Organic acid (as conjugate base) & M4 & M5 & M6 & M7 & M8 & M9 \\
\hline Acetate & 2.7 & 0.1 & 24.6 & 6.5 & 20.1 & 3.3 \\
Propionate & ND & ND & ND & ND & ND & ND \\
Butyrate & 6.4 & 0.4 & 39.7 & 14.8 & 38.3 & 8.0 \\
Lactate & 6.1 & 0.0 & 38.8 & 3.8 & 0.7 & 0.4 \\
\hline
\end{tabular}

M4 to M9 identify the mouse source for caecal contents at each sampling time. ND = Not determined.

\section{Discussion}

In the last decades, RS has been increasingly investigated for its potential to function as a prebiotic agent with the ability to modulate composition and fermentation profiles of intestinal communities, thereby improving human health and well-being [9,15]. Previous reports, in which RS was administrated to mice, rats or pigs showed alterations of the community by increased abundances of Bifidobacterium, Akkermansia, Allobaculum, Lactobacillus, Ruminococcus, Prevotella and several other groups $[17,18,20,43]$, and also increased amounts of SCFA such as acetate, propionate and butyrate $[18,44,45]$. In the case of humans, in particular Ruminococcus bromii was suggested to play a major role in resistant starch digestion and subsequent butyrate production [46], also based on an RNA-SIP study conducted with material from a bioreactor simulating the human intestinal tract [29]. 
However, conventional feeding studies might have been biased by enrichments and generally lacked the ability to directly link the conversion of RS to distinct groups of gut bacteria in their natural habitat. Hence, knowledge about the key players directly involved in the break-down of this complex carbohydrate in situ is still scarce.

Here, we report the use of $\left[\mathrm{U}^{13} \mathrm{C}\right]$-labeled potato starch, a source of RS, as a substrate for the caecal community using mice as model system, and the use of RNA-SIP in combination with high-throughput 16S rRNA sequencing and GC-MS analysis to gain phylogenetic information about the bacteria involved in $\left[\mathrm{U}^{13} \mathrm{C}\right]$ starch degradation in situ. In a previous in vitro study, we had used RNA-SIP to identify bacterial groups from faecal samples of mice that were involved in the in vitro assimilation of $\left[\mathrm{U}^{13} \mathrm{C}\right]$ starch [33]. To the best of our knowledge, the present study represents just the second report on the use of RNA-SIP under in vivo conditions in a vertebrate intestinal system [30], and the first using RS.

The density range of the obtained isopycnic gradients agreed with gradients from previous RNA-SIP studies and included densities necessary to separate isotope-labeled $\left[{ }^{13} \mathrm{C}\right] \mathrm{RNA}$ from unlabeled background RNA [31-33]. The observed shifts of $16 \mathrm{~S}$ rRNA species isolated from [U $\left.{ }^{13} \mathrm{C}\right]$ starch-fed mice towards higher densities, $2 \mathrm{~h}$ and $4 \mathrm{~h}$ after provision of the labeled starch clearly indicated $\left[\mathrm{U}^{13} \mathrm{C}\right.$ ] starch utilization and incorporation of ${ }^{13} \mathrm{C}$ into bacterial $16 \mathrm{~S}$ rRNA. After $2 \mathrm{~h}$ of feeding, labeling of RNA was less pronounced, which might be explained with the digestion-resistant nature of RS, the presence of competing [Unlabeled) substrates in the gut, and the fact that in microbial fermentation processes most of the carbon is used in energy metabolism rather than in biosynthesis processes, such as RNA synthesis [28].

The caecal microbiota analysis of all experimental animals based on unseparated RNA revealed an overall bacterial community structure that is in very good alignment with profiles observed in caecal samples of mice analyzed by conventional 16S sequencing [47-49], indicating a normal (healthy) microbiota in all animals used for this study. In addition, indicated by a clear delineation in hierarchical clustering analysis before the administration of the RS, as well as during the course of fermentation, it is suggested that RS dynamically introduced changes into this microbiota. This is further supported by a significant increasing diversity estimate, which suggests that more and more species benefited from the available RS and/or its degradation products and/or metabolites over time.

Screening of $16 \mathrm{~S}$ amplicon sequencing profiles revealed only a limited number of taxa that were significantly increased in abundance in 'heavy' vs. 'light' gradient fractions, thereby suggesting involvement in the assimilation of the $\left[\mathrm{U}^{13} \mathrm{C}\right]$ starch. Interestingly, only a few of them are related to well-known starch degraders.

With limited significance, Bacteroidaceae and Bacteroides spp. were relatively enriched in 'heavy' RNA, isolated $2 \mathrm{~h}$ after feeding starch. These taxa comprise a particular high number of members that are associated with the utilization of various types of starch and are, therefore, considered to be one of the major amylolytic species in the human colon [50-52]. Starch utilization in Bacteroides spp. is mediated through a well-characterized starch binding and degradation system referred to as starch utilization system (SUS) [53]. Hence, our data allow careful speculation that Bacteroides spp. might have functioned as initial starch degraders here, producing smaller hydrolysis products, e.g., maltose and glucose that served as substrates for other taxa such as Dorea spp. and unclassified Clostridiales, which became significantly labeled during the experiment. This is in line with a previous report demonstrating that gut Bacteroidales significantly contributed to cross-feeding in intestinal ecosystems [54]. Notably, labeled metabolites for cross-feeding might have also resulted from starch hydrolysis mediated by the host itself in the small intestine through the enzymatic activity of pancreatic $\alpha$-amylases, mucosal maltase-glucoamylases and sucrose-isomaltases [55]. However, starch fractions from potatoes were shown to be degraded rather slowly in comparison to other botanical sources in vitro and in vivo [56,57].

Dorea is one of the most dominant human gut genera [58]. Increases in Dorea portions upon a diet enriched with RS were recently reported in mice [59], suggesting that this genus might indeed 
be stimulated by RS within a complex food web. However, other reports showed a decrease of this genus following RS consumption in humans and pigs [20,60,61]. Notably, Dorea species, including Dorea formicigenerans, to which the most abundant OTU from this group was affiliated, are not known to be capable of starch hydrolysis so far [62]. Either, the OTUs classified as Dorea ssp. here represent so-far uncultured species, being capable of starch hydrolysis, or the observed labeling results from cross-feeding on metabolites released from the labeled starch by other bacteria or by the host.

Both explanations also hold true for the other taxa that were found to be enriched in the 'heavy' RNA fraction, as many of them were related to taxa so far not known as starch degraders, such as Turicibacter spp. or Clostridium lactatifermentans $[63,64]$. Interestingly, increases in relative abundances of Turicibacter spp. were also shown in the hindgut of pigs fed raw potato starch [65] and two of the three most abundant OTUs categorized as 'unclassified Clostridiales' appear to be affiliated with Lachnospiraceae, whose members are known for their capacity to degrade several plant-derived polysaccharides including starch [66].

RS is well-known to significantly increase SCFA production in vitro and in vivo [67-69]. In particular, potato starch was associated with elevated butyrate levels in the large bowel of humans, rats and pigs $[44,70,71]$. Butyrate production can either originate from a direct stimulation of butyrate-producing species, mostly associated with members of the Clostridium cluster IV (Ruminococcaceae family) and Clostridium cluster XIVa (Lachnospiraceae family) [72], and/or by cross-feeding between different members of the caecal microbiota [73-75]. Similarly, butyrate was the metabolic product showing the highest level of incorporated label in our study. It might have been directly produced from starch by the metabolic activity of bacteria affiliated with unclassified Clostridiales and the Lachnospiraceae family, which also became significantly labeled during the experiment.

The data obtained here show similarities in comparison to our recently published in vitro data on the fermentation of potato starch by a mice fecal microbiota [33]. While in both experiments, labeled acetate and butyrate were detected, labeled propionate was only detected in vitro, and labeled lactate only in vivo. In vitro, 24 bacterial taxa became significantly ${ }^{13} \mathrm{C}$-labeld, which was now confirmed for Bacteroides and unclassified Clostridiales also under in vivo conditions, thereby strongly suggesting an actual involvement of these groups in intestinal starch degradation.

\section{Conclusions}

Collectively, our data show that the RNA-SIP approach is generally suited to link the structure and function of intestinal microbiotas also under the in situ conditions of mice intestinal tracts. Heavier, i.e., presumably isotopically labeled RNA, could be extracted only $2-4 \mathrm{~h}$ after having fed labeled potato starch to the animals. In addition, a few, but statistically significant differences in microbial community composition between labeled and unlabeled RNA fractions were shown, probably indicating starch-degrading bacteria from the intestinal tract. Bacteria affiliated with Bacteroides and Clostridiales were confirmed as initial starch degraders in the caecal microbiota of mice, while other bacteria related to Clostridiales, Dorea, and Turicibacter might have played a role as cross-feeders on metabolic products, although a direct involvement in starch degradation cannot be ruled out. Clearly, further studies are needed to verify the role of the bacteria suggested as starch degraders and cross-feeders here in more detail. These studies should account for the limitations of our pilot study, i.e., include, for instance, more test and control animals, more sampling points (to address the effect of cross-feeding in more detail), longer incubation times (to achieve a stronger labeling of RNA and metabolites) and ${ }^{12} \mathrm{C}$-controls (to ensure a nutritional balance between test and control animals). Finally, SIP might be used in a more quantitative way, as recently introduced by Hungate and colleagues [76], albeit for DNA-SIP only.

Supplementary Materials: The following are available online at www.mdpi.com/2072-6643/10/2/179/s1, Table S1: Relative abundances (\%) of bacterial taxa based on 16S ribosomal RNA (rRNA) amplified from density-unseparated RNA isolated from individual caecal content samples before $(0 \mathrm{~h})$ and after administration of 
resistant starch (RS; $2 \mathrm{~h}$ and $4 \mathrm{~h}$ ), Table S2: Relative abundance (\%) of those bacterial taxa with significant differences between 'heavy' and 'light' RNA-SIP fractions extracted from caecal content $2 \mathrm{~h}$ and $4 \mathrm{~h}$ after administration of $\left[\mathrm{U}^{13} \mathrm{C}\right]$ starch, Figure S1: Bacterial microbiota composition based on the relative abundances of $16 \mathrm{~S}$ ribosomal RNA (rRNA) sequences of genus-level taxa. Density-unseparated RNA was obtained from caecal contents of mice before $(0 \mathrm{~h})$ or after administration of $\left[\mathrm{U}^{13} \mathrm{C}\right]$ starch $(2 \mathrm{~h}$ and $4 \mathrm{~h})$, Figure S2: Bacterial microbiota composition represented by the relative abundances of $16 \mathrm{~S}$ ribosomal RNA (rRNA) sequences of genus-level taxa in 'heavy' and 'light' density fractions.

Acknowledgments: We thank colleagues from AgResearch Limited and Plant \& Food Research Limited for additionally reviewing the manuscript. This research was partially funded by the "Innovative/Cooperative Projects" program of the German federal state of Baden-Württemberg (Project Präbio-SIP). The funders had no role in the study design or analysis and interpretation of the data. The article processing charge was funded by the Baden-Württemberg Ministry of Science, Research and Culture and Furtwangen University in the funding programme Open Access Publishing.

Author Contributions: E.H., C.U.R. and M.E. conceived and designed the study. E.H., V.R.-G., D.R., H.S. and M.H. performed the experiments. E.H., S.W., W.Y. and D.R. contributed to the analysis of the data. All authors wrote the manuscript and approved the final version of the article.

Conflicts of Interest: The authors declare no conflicts of interest.

\section{References}

1. Riedel, C.U.; Schwiertz, A.; Egert, M. The stomach and small and large intestinal microbiomes. In The Human Microbiota and Microbiome (Advances in Molecular and Cellular Microbiology 25); Marchesi, J.K., Ed.; CABI: Wallingford, UK, 2014; pp. 1-19.

2. Turnbaugh, P.J.; Quince, C.; Faith, J.J.; McHardy, A.C.; Yatsunenko, T.; Niazi, F.; Affourtit, J.; Egholm, M.; Henrissat, B.; Knight, R.; et al. Organismal, genetic, and transcriptional variation in the deeply sequenced gut microbiomes of identical twins. PNAS 2010, 107, 7503-7508. [CrossRef] [PubMed]

3. Turnbaugh, P.J.; Hamady, M.; Yatsunenko, T.; Cantarel, B.L.; Duncan, A.; Ley, R.E.; Sogin, M.L.; Jones, W.J.; Roe, B.A.; Affourtit, J.P.; et al. A core gut microbiome in obese and lean twins. Nature 2009, 457, 480-484. [CrossRef] [PubMed]

4. O'Hara, A.M.; Shanahan, F. The gut flora as a forgotten organ. EMBO Rep. 2006, 7, 688-693. [CrossRef] [PubMed]

5. McNeil, N.I. The contribution of the large intestine to energy supplies in man. Am. J. Clin. Nutr. 1984, 39, 338-342. [CrossRef] [PubMed]

6. Flint, H.J.; Bayer, E.A.; Rincon, M.T.; Lamed, R.; White, B.A. Polysaccharide utilization by gut bacteria: Potential for new insights from genomic analysis. Nat. Rev. Microbiol. 2008, 6, 121-131. [CrossRef] [PubMed]

7. Asp, N.G. Resistant starch. Proceedings for the 2nd plenary meeting of Euresta: European flair concerted action No. 11 on physiological implications of the consumption of resistant starch in man. Crete, 29 May-2 June 1991. Eur. J. Clin. Nutr. 1992, 46 (Suppl. 2), S1-S48.

8. Englyst, H.N.; Kingman, S.M.; Hudson, G.J.; Cummings, J.H. Measurement of resistant starch in vitro and in vivo. Br. J. Nutr. 1996, 75, 749-755. [CrossRef] [PubMed]

9. Birt, D.F.; Boylston, T.; Hendrich, S.; Jane, J.L.; Hollis, J.; Li, L.; McClelland, J.; Moore, S.; Phillips, G.J.; Rowling, M.; et al. Resistant starch: Promise for improving human health. Adv. Nutr. 2013, 4, 587-601. [CrossRef] [PubMed]

10. Englyst, H.N.; Kingman, S.M.; Cummings, J.H. Classification and measurement of nutritionally important starch fractions. Eur. J. Clin. Nutr. 1992, 46 (Suppl. 2), S33-S50. [PubMed]

11. Slavin, J. Fiber and prebiotics: Mechanisms and health benefits. Nutrients 2013, 5, 1417-1435. [CrossRef] [PubMed]

12. Morrison, D.J.; Preston, T. Formation of short chain fatty acids by the gut microbiota and their impact on human metabolism. Gut Microbes 2016, 7, 189-200. [CrossRef] [PubMed]

13. Sekirov, I.; Russell, S.L.; Antunes, L.C.; Finlay, B.B. Gut microbiota in health and disease. Physiol. Rev. 2010, 90, 859-904. [CrossRef] [PubMed]

14. Walsh, C.J.; Guinane, C.M.; O'Toole, P.W.; Cotter, P.D. Beneficial modulation of the gut microbiota. FEBS Lett. 2014, 588, 4120-4130. [CrossRef] [PubMed]

15. Nugent, A.P. Health properties of resistant starch. BNF Nutr. Bull. 2005, 30, 27-54. [CrossRef] 
16. Higgins, J.A.; Brown, I.L. Resistant starch: A promising dietary agent for the prevention/treatment of inflammatory bowel disease and bowel cancer. Curr. Opin. Gastroenterol. 2013, 29, 190-194. [CrossRef] [PubMed]

17. Young, W.; Roy, N.C.; Lee, J.; Lawley, B.; Otter, D.; Henderson, G.; McCann, M.J.; Tannock, G.W. Changes in bowel microbiota induced by feeding weanlings resistant starch stimulate transcriptomic and physiological responses. Appl. Environ. Microbiol. 2012, 78, 6656-6664. [CrossRef] [PubMed]

18. Kleessen, B.; Stoof, G.; Proll, J.; Schmiedl, D.; Noack, J.; Blaut, M. Feeding resistant starch affects fecal and cecal microflora and short-chain fatty acids in rats. J. Anim. Sci. 1997, 75, 2453-2462. [CrossRef] [PubMed]

19. Silvi, S.; Rumney, C.J.; Cresci, A.; Rowland, I.R. Resistant starch modifies gut microflora and microbial metabolism in human flora-associated rats inoculated with faeces from Italian and UK donors. J. Appl. Microbiol. 1999, 86, 521-530. [CrossRef] [PubMed]

20. Umu, O.C.; Frank, J.A.; Fangel, J.U.; Oostindjer, M.; da Silva, C.S.; Bolhuis, E.J.; Bosch, G.; Willats, W.G.; Pope, P.B.; Diep, D.B. Resistant starch diet induces change in the swine microbiome and a predominance of beneficial bacterial populations. Microbiome 2015, 3, 16. [CrossRef] [PubMed]

21. Radajewski, S.; Ineson, P.; Parekh, N.R.; Murrell, J.C. Stable-isotope probing as a tool in microbial ecology. Nature 2000, 403, 646-649. [CrossRef] [PubMed]

22. Boschker, H.T.S.; Nold, S.C.; Wellsbury, P.; Bos, D.; de Graaf, W.; Pel, R.; Parkes, R.J.; Cappenberg, T.E. Direct linking of microbial populations to specific biogeochemical processes by ${ }^{13} \mathrm{C}$-labelling of biomarkers. Nature 1998, 392, 801-805. [CrossRef]

23. Dumont, M.G.; Murrell, J.C. Stable isotope probing-Linking microbial identity to function. Nat. Rev. Microbiol. 2005, 3, 499-504. [CrossRef] [PubMed]

24. Neufeld, J.D.; Dumont, M.G.; Vohra, J.; Murrell, J.C. Methodological considerations for the use of stable isotope probing in microbial ecology. Microb. Ecol. 2007, 53, 435-442. [CrossRef] [PubMed]

25. Egert, M.; de Graaf, A.A.; Smidt, H.; de Vos, W.M.; Venema, K. Beyond diversity: Functional microbiomics of the human colon. Trends Microbiol. 2006, 14, 86-91. [CrossRef] [PubMed]

26. Manefield, M.; Whiteley, A.S.; Ostle, N.; Ineson, P.; Bailey, M.J. Technical considerations for RNA-based stable isotope probing: An approach to associating microbial diversity with microbial community function. Rapid Commun. Mass Spectrom. 2002, 16, 2179-2183. [CrossRef] [PubMed]

27. Manefield, M.; Whiteley, A.S.; Griffiths, R.I.; Bailey, M.J. RNA stable isotope probing, a novel means of linking microbial community function to phylogeny. Appl. Environ. Microbiol. 2002, 68, 5367-5373. [CrossRef] [PubMed]

28. Egert, M.; de Graaf, A.A.; Maathuis, A.; de Waard, P.; Plugge, C.M.; Smidt, H.; Deutz, N.E.; Dijkema, C.; de Vos, W.M.; Venema, K. Identification of glucose-fermenting bacteria present in an in vitro model of the human intestine by RNA-stable isotope probing. FEMS Microbial. Ecol. 2007, 60, 126-135. [CrossRef] [PubMed]

29. Kovatcheva-Datchary, P.; Egert, M.; Maathuis, A.; Rajilic-Stojanovic, M.; de Graaf, A.A.; Smidt, H.; de Vos, W.M.; Venema, K. Linking phylogenetic identities of bacteria to starch fermentation in an in vitro model of the large intestine by RNA-based stable isotope probing. Environ. Microbiol. 2009, 11, 914-926. [CrossRef] [PubMed]

30. Tannock, G.W.; Lawley, B.; Munro, K.; Sims, I.M.; Lee, J.; Butts, C.A.; Roy, N. RNA-stable-isotope probing shows utilization of carbon from inulin by specific bacterial populations in the rat large bowel. Appl. Environ. Microbiol. 2014, 80, 2240-2247. [CrossRef] [PubMed]

31. Young, W.; Egert, M.; Bassett, S.A.; Bibiloni, R. Detection of sialic acid-utilising bacteria in a caecal community batch culture using RNA-based stable isotope probing. Nutrients 2015, 7, 2109-2124. [CrossRef] [PubMed]

32. Herrmann, E.; Young, W.; Rosendale, D.; Reichert-Grimm, V.; Riedel, C.U.; Conrad, R.; Egert, M. RNA-based stable isotope probing suggests Allobaculum spp. as particularly active glucose assimilators in a complex murine microbiota cultured in vitro. Biomed. Res. Int. 2017, 2017, 1829685. [CrossRef] [PubMed]

33. Herrmann, E.; Young, W.; Rosendale, D.; Conrad, R.; Riedel, C.U.; Egert, M. Determination of resistant starch assimilating bacteria in fecal samples of mice by in vitro RNA-based stable isotope probing. Front. Microbiol. 2017, 8, 1331. [CrossRef] [PubMed]

34. Furet, J.P.; Firmesse, O.; Gourmelon, M.; Bridonneau, C.; Tap, J.; Mondot, S.; Dore, J.; Corthier, G. Comparative assessment of human and farm animal faecal microbiota using real-time quantitative PCR. FEMS Microbiol. Ecol. 2009, 68, 351-362. [CrossRef] [PubMed] 
35. Herrmann, E.; Koch, P.; Riedel, C.U.; Young, W.; Egert, M. Effect of rotor type on the separation of isotope-labeled and unlabeled Escherichia coli RNA by isopycnic density ultracentrifugation. Can. J. Microbiol. 2017, 63, 83-87. [CrossRef] [PubMed]

36. Lueders, T.; Manefield, M.; Friedrich, M.W. Enhanced sensitivity of DNA- and rRNA-based stable isotope probing by fractionation and quantitative analysis of isopycnic centrifugation gradients. Environ. Microbiol. 2004, 6, 73-78. [CrossRef] [PubMed]

37. Caporaso, J.G.; Kuczynski, J.; Stombaugh, J.; Bittinger, K.; Bushman, F.D.; Costello, E.K.; Fierer, N.; Pena, A.G.; Goodrich, J.K.; Gordon, J.I.; et al. QIIME allows analysis of high-throughput community sequencing data. Nat. Methods 2010, 7, 335-336. [CrossRef] [PubMed]

38. R Core Team. R: A Language and Environment for Statistical Computing; R Foundation for Statistical Computing: Vienna, Austria, 2015; ISBN 3-900051-07-0. Available online: http://www.R-project.Org/ (accessed on 21 November 2017).

39. Hervé, M. RVAideMemoire: Diverse Basic Statistical and Graphical Functions. R package version 0.9-45-2. 2015. Available online: https:/ / cran.r-project.org/web/packages/RVAideMemoire/index.html (accessed on 1 February 2018).

40. Altschul, S.F.; Gish, W.; Miller, W.; Myers, E.W.; Lipman, D.J. Basic local alignment search tool. J. Mol. Biol. 1990, 215, 403-410. [CrossRef]

41. Richardson, A.J.; Calder, A.G.; Stewart, C.S. Simultaneous determination of volatile and non-volatile acidic fermentation products of anaerobes by capillary Gas-Chromatography. Lett. Appl. Microbiol. 1989, 9, 5-8. [CrossRef]

42. Slater, C.; Preston, T.; Weaver, L.T. Stable isotopes and the international system of units. Rapid Commun. Mass Spectrom. 2001, 15, 1270-1273. [CrossRef] [PubMed]

43. Tachon, S.; Zhou, J.; Keenan, M.; Martin, R.; Marco, M.L. The intestinal microbiota in aged mice is modulated by dietary resistant starch and correlated with improvements in host responses. FEMS Microbiol. Ecol. 2013, 83, 299-309. [CrossRef] [PubMed]

44. Ferguson, L.R.; Tasman-Jones, C.; Englyst, H.; Harris, P.J. Comparative effects of three resistant starch preparations on transit time and short-chain fatty acid production in rats. Nutr. Cancer 2000, 36, 230-237. [CrossRef] [PubMed]

45. Charrier, J.A.; Martin, R.J.; McCutcheon, K.L.; Raggio, A.M.; Goldsmith, F.; Goita, M.; Senevirathne, R.N.; Brown, I.L.; Pelkman, C.; Zhou, J.; et al. High fat diet partially attenuates fermentation responses in rats fed resistant starch from high-amylose maize. Obesity (Silver Spring) 2013, 21, 2350-2355. [CrossRef] [PubMed]

46. Ze, X.; Duncan, S.H.; Louis, P.; Flint, H.J. Ruminococcus bromii is a keystone species for the degradation of resistant starch in the human colon. ISME J. 2012, 6, 1535-1543. [CrossRef] [PubMed]

47. Brinkman, B.M.; Hildebrand, F.; Kubica, M.; Goosens, D.; Del Favero, J.; Declercq, W.; Raes, J.; Vandenabeele, P. Caspase deficiency alters the murine gut microbiome. Cell Death Dis. 2011, 2, e220. [CrossRef] [PubMed]

48. Gu, S.; Chen, D.; Zhang, J.N.; Lv, X.; Wang, K.; Duan, L.P.; Nie, Y.; Wu, X.L. Bacterial community mapping of the mouse gastrointestinal tract. PLoS ONE 2013, 8, e74957. [CrossRef] [PubMed]

49. Hildebrand, F.; Nguyen, T.L.; Brinkman, B.; Yunta, R.G.; Cauwe, B.; Vandenabeele, P.; Liston, A.; Raes, J. Inflammation-associated enterotypes, host genotype, cage and inter-individual effects drive gut microbiota variation in common laboratory mice. Genome Biol. 2013, 14, R4. [CrossRef] [PubMed]

50. Salyers, A.A.; Vercellotti, J.R.; West, S.E.; Wilkins, T.D. Fermentation of mucin and plant polysaccharides by strains of Bacteroides from the human colon. Appl. Environ. Microbiol. 1977, 33, 319-322. [PubMed]

51. Salyers, A.A.; West, S.E.; Vercellotti, J.R.; Wilkins, T.D. Fermentation of mucins and plant polysaccharides by anaerobic bacteria from the human colon. Appl. Environ. Microbiol. 1977, 34, 529-533. [PubMed]

52. Macfarlane, G.T.; Englyst, H.N. Starch utilization by the human large intestinal microflora. J. Appl. Bacteriol. 1986, 60, 195-201. [CrossRef] [PubMed]

53. Martens, E.C.; Koropatkin, N.M.; Smith, T.J.; Gordon, J.I. Complex glycan catabolism by the human gut microbiota: The Bacteroidetes sus-like paradigm. J. Biol. Chem. 2009, 284, 24673-24677. [CrossRef] [PubMed]

54. Rakoff-Nahoum, S.; Coyne, M.J.; Comstock, L.E. An ecological network of polysaccharide utilization among human intestinal symbionts. Curr. Biol. 2014, 24, 40-49. [CrossRef] [PubMed] 
55. Nichols, B.L.; Avery, S.; Sen, P.; Swallow, D.M.; Hahn, D.; Sterchi, E. The maltase-glucoamylase gene: Common ancestry to sucrase-isomaltase with complementary starch digestion activities. Proc. Natl. Acad. Sci. USA 2003, 100, 1432-1437. [CrossRef] [PubMed]

56. Morita, T.; Hino, S.; Ito, A.; Han, K.H.; Shimada, K.; Fukushima, M. Slower fermentation rate of potato starch relative to high-amylose cornstarch contributes to the higher proportion of cecal butyrate in rats. BMFH 2013, 32, 149-156. [CrossRef] [PubMed]

57. De Rocha, T.S.; de Carneiro, A.P.A.; Franco, C.M.L. Effect of enzymatic hydrolysis on some physicochemical properties of root and tuber granular starches. Food Sci. Technol. (Campinas) 2010, 30, 544-551. [CrossRef]

58. Qin, J.; Li, R.; Raes, J.; Arumugam, M.; Burgdorf, K.S.; Manichanh, C.; Nielsen, T.; Pons, N.; Levenez, F.; Yamada, T.; et al. A human gut microbial gene catalogue established by metagenomic sequencing. Nature 2010, 464, 59-65. [CrossRef] [PubMed]

59. Jiminez, J.A.; Uwiera, T.C.; Abbott, D.W.; Uwiera, R.R.E.; Inglis, G.D. Impacts of resistant starch and wheat bran consumption on enteric inflammation in relation to colonic bacterial community structures and short-chain fatty acid concentrations in mice. Gut Pathog. 2016, 8, 67. [CrossRef] [PubMed]

60. Martinez, I.; Kim, J.; Duffy, P.R.; Schlegel, V.L.; Walter, J. Resistant starches types 2 and 4 have differential effects on the composition of the fecal microbiota in human subjects. PLoS ONE 2010, 5, e15046. [CrossRef] [PubMed]

61. Upadhyaya, B.; McCormack, L.; Fardin-Kia, A.R.; Juenemann, R.; Nichenametla, S.; Clapper, J.; Specker, B.; Dey, M. Impact of dietary resistant starch type 4 on human gut microbiota and immunometabolic functions. Sci. Rep. 2016, 6, 28797. [CrossRef] [PubMed]

62. Taras, D.; Simmering, R.; Collins, M.D.; Lawson, P.A.; Blaut, M. Reclassification of Eubacterium formicigenerans Holdeman and Moore 1974 as Dorea formicigenerans gen. nov., comb. nov., and description of Dorea longicatena sp. nov., isolated from human faeces. Int. J. Syst. Evol. Microbiol. 2002, 52, 423-428. [CrossRef] [PubMed]

63. Bosshard, P.P.; Zbinden, R.; Altwegg, M. Turicibacter sanguinis gen. nov., sp. nov., a novel anaerobic, gram-positive bacterium. Int. J. Syst. Evol. Microbiol. 2002, 52, 1263-1266. [PubMed]

64. Van der Wielen, P.W.; Rovers, G.M.; Scheepens, J.M.; Biesterveld, S. Clostridium lactatifermentans sp. nov., a lactate-fermenting anaerobe isolated from the caeca of a chicken. Int. J. Syst. Evol. Microbiol. 2002, 52, 921-925. [CrossRef] [PubMed]

65. Sun, Y.; Su, Y.; Zhu, W. Microbiome-metabolome responses in the cecum and colon of pig to a high resistant starch diet. Front. Microbiol. 2016, 7, 779. [CrossRef] [PubMed]

66. Biddle, A.; Stewart, L.; Blanchard, J.; Leschine, S. Untangling the genetic basis of fibrolytic specialization by Lachnospiraceae and Ruminococcaceae in diverse gut communities. Diversity 2013, 5, 627-640. [CrossRef]

67. Giuberti, G.; Gallo, A.; Moschini, M.; Masoero, F. In vitro production of short-chain fatty acids from resistant starch by pig faecal inoculum. Animal 2013, 7, 1446-1453. [CrossRef] [PubMed]

68. Le Leu, R.K.; Hu, Y.; Brown, I.L.; Young, G.P. Effect of high amylose maize starches on colonic fermentation and apoptotic response to DNA-damage in the colon of rats. Nutr. Metab. (Lond.) 2009, 6, 11. [CrossRef] [PubMed]

69. Le Leu, R.K.; Brown, I.L.; Hu, Y.; Morita, T.; Esterman, A.; Young, G.P. Effect of dietary resistant starch and protein on colonic fermentation and intestinal tumourigenesis in rats. Carcinogenesis 2007, 28, 240-245. [CrossRef] [PubMed]

70. Cummings, J.H.; Beatty, E.R.; Kingman, S.M.; Bingham, S.A.; Englyst, H.N. Digestion and physiological properties of resistant starch in the human large bowel. Br. J. Nutr. 1996, 75, 733-747. [CrossRef] [PubMed]

71. Martin, L.J.; Dumon, H.J.; Lecannu, G.; Champ, M.M. Potato and high-amylose maize starches are not equivalent producers of butyrate for the colonic mucosa. Br. J. Nutr. 2000, 84, 689-696. [PubMed]

72. Louis, P.; Flint, H.J. Formation of propionate and butyrate by the human colonic microbiota. Environ. Microbiol. 2017, 19, 29-41. [CrossRef] [PubMed]

73. Duncan, S.H.; Louis, P.; Flint, H.J. Lactate-utilizing bacteria, isolated from human feces, that produce butyrate as a major fermentation product. Appl. Environ. Microbiol. 2004, 70, 5810-5817. [CrossRef] [PubMed]

74. Belenguer, A.; Duncan, S.H.; Calder, A.G.; Holtrop, G.; Louis, P.; Lobley, G.E.; Flint, H.J. Two routes of metabolic cross-feeding between bifidobacterium adolescentis and butyrate-producing anaerobes from the human gut. Appl. Environ. Microbiol. 2006, 72, 3593-3599. [CrossRef] [PubMed] 
75. Rios-Covian, D.; Gueimonde, M.; Duncan, S.H.; Flint, H.J.; de los Reyes-Gavilan, C.G. Enhanced butyrate formation by cross-feeding between Faecalibacterium prausnitzii and Bifidobacterium adolescentis. FEMS Microbiol. Lett. 2015, 362, fnv176. [CrossRef] [PubMed]

76. Hungate, B.A.; Mau, R.L.; Schwartz, E.; Caporaso, J.G.; Dijkstra, P.; van Gestel, N.; Koch, B.J.; Liu, C.M.; McHugh, T.A.; Marks, J.C.; et al. Quantitative microbial ecology through stable isotope probing. Appl. Environ. Microbiol. 2015, 81, 7570-7581. [CrossRef] [PubMed] 